\title{
Performed Histopathology
}

National Cancer Institute

\section{Source}

National Cancer Institute. Performed Histopathology. NCI Thesaurus. Code C93427.

The completed assessment for findings from a microscopic study of characteristic tissue abnormalities by employing various cytochemical and immunocytochemical stains. 